\title{
Temperature regulation of bacterial production, respiration, and growth efficiency in a temperate salt-marsh estuary
}

\author{
Jude K. Apple ${ }^{1,2, *}$, P. A. del Giorgio ${ }^{3}$, W. Michael Kemp ${ }^{1}$ \\ ${ }^{1}$ Horn Point Laboratory, University of Maryland Center for Environmental Science, Cambridge, Maryland 21613, USA \\ ${ }^{2}$ US Naval Research Laboratory, Washington, DC 20375, USA \\ ${ }^{3}$ Département des sciences biologiques, Université du Québec à Montréal (UQÀM), Montréal H3C 3P8, Canada
}

\begin{abstract}
There is consensus that temperature plays a major role in shaping microbial activity, but there are still questions as to how temperature influences different aspects of bacterioplankton carbon metabolism under different environmental conditions. We examined the temperature dependence of bacterioplankton carbon metabolism, whether this temperature dependence changes at different temperatures, and whether the relationship between temperature and carbon metabolism varies among estuarine sub-systems differing in their degree of enrichment. Two years of intensive sampling in a temperate estuary (Monie Bay, Chesapeake Bay, USA) revealed significant differences in the temperature dependence of bacterial production (BP) and respiration (BR), which drove a strong negative temperature response of bacterial growth efficiency (BGE). Accordingly, BGE was lower in summer $(<0.2)$ and higher in winter $(>0.5)$. For all measured metabolic processes, the most pronounced temperature response was observed at lower temperatures, with $Q_{10}$ values generally 2 -fold greater than in warmer waters. Despite significant differences in resource availability, both the temperature dependence and magnitude of BR and bacterioplankton carbon consumption (BCC) were remarkably similar among the 4 estuarine sub-systems. Although temperature dependencies of $\mathrm{BP}$ and BGE were also similar, their magnitude differed significantly, with highest values in the nutrient-enriched sub-system and lowest in the open bay. This pattern in carbon metabolism among subsystems was present throughout the year and was confirmed by temperature manipulation experiments, suggesting the temperature effects on BP and BGE did not override the influence of resource availability. We conclude that temperature is the dominant factor regulating seasonality of BR and $\mathrm{BCC}$ in this system, whereas BP and BGE are influenced by both temperature and organic matter quality, with variation in the relative importance of each of these factors throughout the year.
\end{abstract}

KEY WORDS: Bacterioplankton · Temperature $\cdot$ Growth efficiency · Estuary

\section{INTRODUCTION}

It is well established that temperature plays a fundamental role in regulating the activity and growth of all microorganisms (Rose 1967, Madigan et al. 2003). The effect of temperature on cellular processes in cultured bacteria has been well documented, with a general consensus that metabolic rates approximately double for each $10^{\circ} \mathrm{C}$ increase in temperature (Morita 1974). This general rule often masks the fact that the temper- ature dependence of different biochemical processes can vary greatly. Disparate effects of temperature have been documented for the uptake of various forms of inorganic nitrogen and different amino acids (Crawford et al. 1974, Reay et al. 1999), enzymatic activity, and variability in the coupling of cellular respiration to ATP production (Rose 1967). Furthermore, temperature manipulation experiments conducted on bacterial cultures reveal a difference in the response of cellular growth versus respiration (Rose 1967), indicating that 
differences in temperature dependence are evident at multiple levels of cellular organization.

Although there is no reason to think that bacterioplankton should respond to temperature any differently than cultured bacteria, the results obtained from single bacterial cultures are often difficult to extrapolate to complex microbial communities. The effect of temperature on bacterioplankton carbon metabolism has been the subject of numerous studies (Hoch \& Kirchman 1993, Sampou \& Kemp 1994, Shiah \& Ducklow 1994b, Pomeroy et al. 1995, Felip et al. 1996, Raymond \& Bauer 2000). The majority of these have focused on the temperature dependence of bacterial growth rates and production (BP) alone. In general, these studies share 2 fundamental conclusions. First, that the temperature dependence of bacterial growth and production is stronger at lower temperatures and, second, that the effect of temperature is often modulated by other environmental conditions, namely the availability of inorganic nutrients and the quality and quantity of organic matter substrates.

Fewer studies are available that have investigated the effect of temperature on bacterioplankton respiration (BR) in coastal and marine systems (Jahnke \& Craven 1995, del Giorgio \& Williams 2005). The strong temperature dependence of BR has been observed in cold water $\left(<4^{\circ} \mathrm{C}\right)$ systems (Griffiths et al. 1984, Pomeroy \& Deibel 1986, Pomeroy et al. 1991), although temperature adaptation of psychrophilic bacterioplankton suggests that these relationships may not necessarily represent the temperature dependence of microbial communities in temperate systems (Rose 1967). Studies of BR in temperate coastal systems generally report a positive temperature-respiration relationship that is often more robust than that of BP and less susceptible to the influence of other environmental conditions (Iturriaga \& Hoppe 1977, Sampou \& Kemp 1994, Pomeroy et al. 1995). A limited number of studies have reported a positive effect of temperature on total carbon consumption (Raymond \& Bauer 2000), suggesting that bacterioplankton carbon consumption (BCC) may reflect the temperature dependence of BR in similar coastal or estuarine systems. However, although these studies collectively indicate that temperature exerts a strong positive effect on respiration, the few available empirical estimates vary greatly and it is unclear if there is a regular pattern in the temperature dependence of $\mathrm{BR}$ - or BGE and BCC - across coastal or estuarine systems.

Differences in the pattern of the temperature dependence of BP and BR suggested by these studies (e.g. Iturriaga \& Hoppe 1977, Sampou \& Kemp 1994, Shiah \& Ducklow 1994b, Pomeroy et al. 1995) further imply an inherent temperature dependence of bacterial growth efficiency (i.e. $\mathrm{BGE}=\mathrm{BP} /(\mathrm{BP}+\mathrm{BR})$ ). However, direct investigations of the effect of temperature on BGE in aquatic systems are very few and have not come to any consensus. Some manipulative experiments suggest that BGE decreases with increasing temperature (Iturriaga \& Hoppe 1977, Tison \& Pope 1980, Griffiths et al. 1984, Roland \& Cole 1999), while other similar studies report no such temperature effect (Crawford et al. 1974). Surveys of seasonal variability have also yielded conflicting results, reporting negative (Bjørnsen 1986, Daneri et al. 1994), positive (Roland \& Cole 1999, Lee et al. 2002, Reinthaler \& Herndl 2005), and little or no effect of temperature (Kroer 1993, Toolan 2001, Ram et al. 2003) on BGE. It is unclear to what extent these discrepancies are due to differences in methodology, lack of sufficient observations, or reflect a true diversity in the effects of temperature on microbial carbon metabolism in different aquatic ecosystems.

In summary, the influence of temperature on bacterioplankton carbon metabolism is both complex and diverse, and in spite of abundant literature on the subject there are still major gaps in our understanding. These gaps are, in part, due to the scarcity of longerterm studies that have simultaneously measured bacterial growth, production, and respiration (Jahnke \& Craven 1995, Reinthaler \& Herndl 2005), which would allow truly comparable rates to be derived that are also appropriate for estimating BGE and identifying its temperature dependence. In the current paper, we present results from an intensive 2 yr study carried out in a temperate salt-marsh estuary that experiences a wide range of ambient water temperatures and steep gradients in water-quality parameters. The effect of inorganic nutrients and organic matter quality on bacterioplankton carbon metabolism in this system has been addressed previously (Apple et al. 2004, Apple 2005). We now focus on the effect of temperature, investigating 3 fundamental questions regarding the temperature dependence of bacterioplankton carbon metabolism. First, do different measures of carbon metabolism (i.e. BP, BR, BCC, and BGE) exhibit similar temperature dependence? Second, is the temperature dependence of each measure of carbon metabolism the same for all temperature ranges? And third, does the relationship between temperature and carbon metabolism vary among systems differing in their degree of nutrient and organic carbon enrichment?

\section{MATERIALS AND METHODS}

Our study was conducted in the Monie Bay component of Maryland's National Estuarine Research Reserve (NERR), a tidally influenced temperate salt-marsh estuary located on the eastern shore of Chesapeake Bay 
$\left(38^{\circ} 13.50^{\prime} \mathrm{N}, 75^{\circ} 50.00^{\prime} \mathrm{W}\right)$, consisting of an open bay (OB) and 3 tidal creeks varying in size and watershed characteristics (Fig. 1). Monie Creek (MC) and Little Monie Creek (LMC) are characterized by elevated nutrient concentrations attributed to the agricultural land-use dominating the watershed, whereas Little Creek (LC) is a relatively pristine tidal-creek system, with an undeveloped watershed consisting primarily of marsh and forest (Jones et al. 1997, Apple et al. 2004). These tidal creeks offer a broad range of environmental conditions, including salinity, quality and quantity of dissolved organic matter, and dissolved nutrient concentrations that change on relatively small spatial scales (Table 1, Fig. 1). The utility of this system for investigating the relationship between environmental conditions and bacterioplankton community metabolism has been described previously by our group (Apple et al. 2004).

Thirteen stations within the 4 subsystems of Monie Bay research reserve were visited monthly between March 2000 and January 2002, with biweekly sampling during summer months (June to August). Approximately 201 of nearsurface $(<0.5 \mathrm{~m})$ water were collected in the morning (between 08:00 and 10:00 h), immediately following high tide. Water temperature and salinity were recorded at each station. Water samples were transported back to the laboratory for filtration within approxi- mately $1 \mathrm{~h}$. Upon return to the laboratory, a small subsample was removed from each carboy for determining total bacterioplankton production and abundance.

Estimates of filtered bacterial production, respiration, and abundance were determined following methods detailed elsewhere (del Giorgio \& Bouvier 2002, Apple 2005). Briefly, several liters of sample water were gently passed through an AP15 Millipore filter $(\sim 1 \mu \mathrm{m})$ using a peristaltic pump, then incubating in the dark in a 81 incubation assembly at in situ field temperature. Total BP was also determined directly using unfiltered water samples. Incubations were sub-sampled at 0,3 , and $6 \mathrm{~h}$. BP was estimated using ${ }^{3} \mathrm{H}$-leucine incorporation rates following modifications of Smith \& Azam (1992) and assuming a carbon conversion factor of $3.1 \mathrm{~kg} \mathrm{C} \cdot \mathrm{mol} \mathrm{leu}^{-1}$ (Kirchman 1993). BR was determined by measuring the decline in oxygen concentration over the course of the

Table 1. Two-year means for watershed land use and environmental conditions in each of the sub-systems of Monie Bay National Estuarine Research Reserve (DOM: dissolved organic matter)

\begin{tabular}{|lcccc|}
\hline & $\begin{array}{c}\text { Little } \\
\text { Monie Creek }\end{array}$ & $\begin{array}{c}\text { Monie } \\
\text { Creek }\end{array}$ & $\begin{array}{c}\text { Little } \\
\text { Creek }\end{array}$ & $\begin{array}{c}\text { Open } \\
\text { bay }\end{array}$ \\
\hline Agricultural land use & $25 \%$ & $23 \%$ & $<1 \%$ & $3 \%$ \\
Salinity & 9.9 & 6.9 & 11.6 & 12.1 \\
Total dissolved nitrogen $(\mu \mathrm{M})$ & 40.1 & 40.6 & 26.8 & 28.1 \\
Total dissolved phosphorus $(\mu \mathrm{M})$ & 0.78 & 0.65 & 0.21 & 0.25 \\
Dissolved organic matter $\left(\mathrm{mg} \mathrm{l}^{-1}\right)$ & 8.9 & 11.5 & 7.7 & 6.0 \\
Colored DOM $\left(a_{350}\right)$ & 17 & 20 & 15 & 12 \\
\hline
\end{tabular}
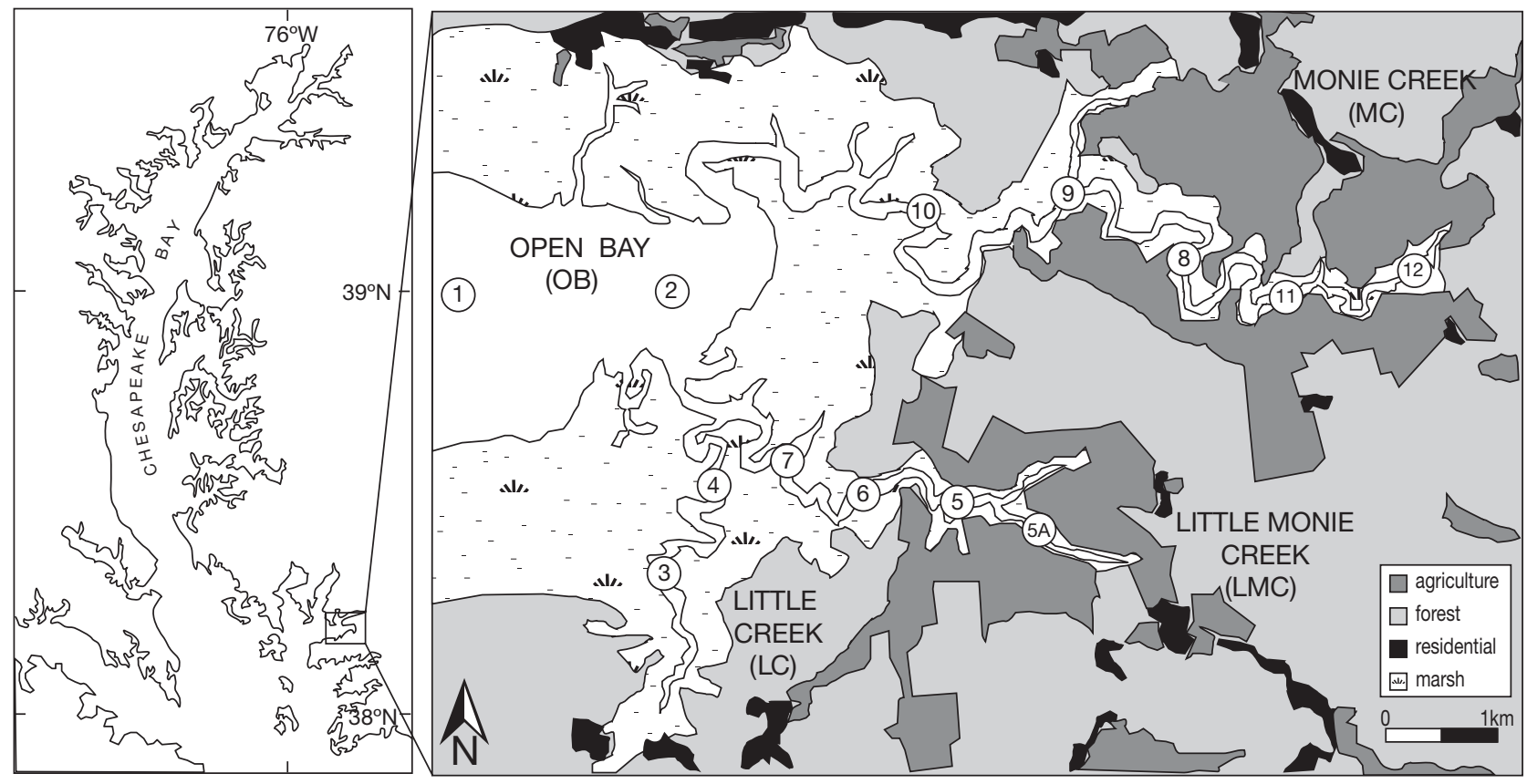

Fig. 1. Study site (Monie Bay, Maryland's National Estuarine Research Reserve), with location and number of each sampling station. Land use is designated as agriculture, forest, residential, and marsh 
$6 \mathrm{~h}$ incubation, with longer incubations ( $8 \mathrm{~h}$ ) used at lower ambient water temperatures $\left(<15^{\circ} \mathrm{C}\right)$. Dissolved oxygen concentrations were measured using membrane-inlet mass spectrometry (Kana et al. 1994). BCC was calculated by adding contemporaneous measurements of filtered BP and BR. Bacterial growth efficiency was calculated as the ratio of filtered $\mathrm{BP}$ and $\mathrm{BCC}[\mathrm{BGE}=$ $\mathrm{BP} /(\mathrm{BP}+\mathrm{BR})]$. Bacterial abundance $(\mathrm{BA})$ was determined on live samples using standard flow-cytometric techniques and the nucleic acid stain SYTO-13 (del Giorgio et al. 1996). Estimates of BA, BR, and BP were used to calculate cell-specific respiration $\left(\mathrm{BR}_{\mathrm{sp}}\right)$ and production $\left(\mathrm{BP}_{\mathrm{sp}}\right)$, the latter of which was used as a proxy for growth.

Simple least-squares regression analysis was used to identify the relationship between temperature and measured metabolic rates, where bacterial rates were log-transformed to meet requirements for normal distribution and regressed against in situ temperatures. Type I regressions were used because local scale $(<100 \mathrm{~m})$ variations in diel mean water temperature and measurement errors were small (Jones et al. 1997). The temperature dependence of different aspects of bacterioplankton carbon metabolism was identified using the slope of least-squares regression. For each measured metabolic rate or efficiency, differences in the effect of temperature (slope) and the effect attributed to each estuarine sub-system ( $y$-intercept) were identified using ANCOVA, with temperature and creek system as model effects (JMP 5.0; SAS Institute) and Student's $t$-test (Zar 1984). Analyses of the temperature versus BP relationship were also performed on a composite dataset of simultaneous measures of BP and ambient water temperature $(n=279)$ reported in 9 different studies conducted in a range of temperate estuarine systems, including mainstem Chesapeake Bay (Shiah \& Ducklow 1994a,b, Smith 2000), Choptank River (Shiah \& Ducklow 1994a, del Giorgio \& Bouvier 2002), Delaware Bay (Hoch \& Kirchman 1993), Long Island Sound (Anderson \& Taylor 2001), Roskilde Fjord (Bjørnsen et al. 1989), St. Lawrence River (Vincent et al. 1996), and Urdaibai Estuary (Revilla et al. 2000).

Environmental $Q_{10}$ values were derived from in situ water temperatures and measured or calculated parameters using the following equation:

$$
Q_{10}=\left(R_{1} / R_{2}\right)^{10 /\left(T_{1}-T_{2}\right)}
$$

in which $R_{1}$ and $R_{2}$ are rates or efficiencies at 2 temperature extremes (i.e. $T_{1}$ and $T_{2}$, respectively), where $T_{1}>T_{2}$ (Caron et al. 1990, Sherr \& Sherr 1996). $R_{1}$ and $R_{2}$ were predicted using the equation derived from linear regression of observed rates of carbon metabolism (or efficiencies) and the corresponding ambient water temperature in degrees Celsius.
The direct effect of temperature on carbon metabolism was investigated further using temperature manipulation experiments. In the spring of 2004, samples were collected from each estuarine sub-system and incubated at both ambient $\left(18^{\circ} \mathrm{C}\right)$ and manipulated $\left(7^{\circ} \mathrm{C}\right)$ temperatures. Rates of bacterioplankton carbon metabolism associated with these changes in temperature were determined following the methods described previously and compared to regressions describing the temperature response of natural bacterioplankton communities as identified by our field data.

\section{RESULTS}

Arrhenius plots revealed a highly significant positive effect of temperature on both BR and BP when the $30^{\circ} \mathrm{C}$ in situ temperature range was considered (Fig. 2), although the slope describing the relationship between BP and temperature was significantly lower than that of BR (ANCOVA: $\mathrm{r}^{2}=0.49 ; \mathrm{n}=277 ; F=87.7$; $\mathrm{p}<0.0001$ ) and characterized by greater variability at higher temperatures. BCC (regression not shown) exhibited a positive slope intermediate to the slopes of
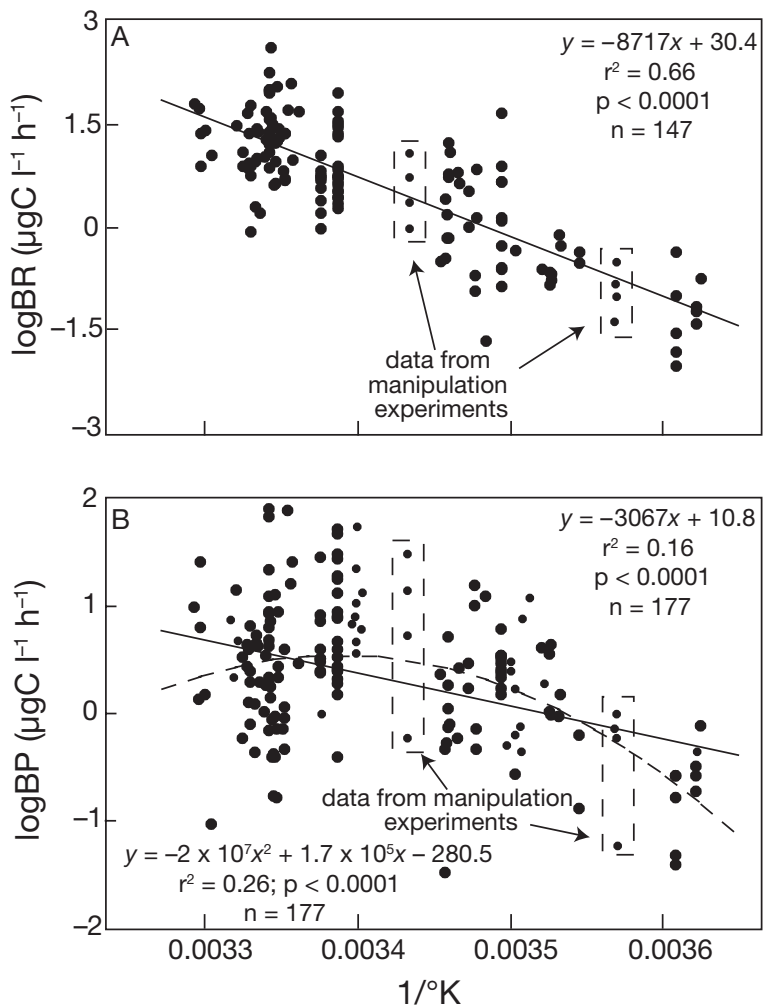

Fig. 2. Arrhenius plots illustrating the temperature dependence of (A) bacterial respiration (BR) and (B) bacterial production (BP). Data from temperature manipulation experiments are indicated by enclosures. Regression statistics are reported in Table 2 
BR and BP. Of these 3 measures of carbon metabolism, $\mathrm{BR}$ exhibited the strongest temperature dependence $\left(\mathrm{r}^{2}=0.66\right)$, followed by BCC $\left(\mathrm{r}^{2}=0.60\right)$ and BP $\left(\mathrm{r}^{2}=\right.$ 0.16). Data from temperature manipulation experiments (Fig. 2, enclosures) adhered to the same trend as field observations and were well predicted by the corresponding regression models. Details of these and other temperature dependencies (i.e. $\mathrm{BA}_{\mathrm{s}} \mathrm{BR}_{\mathrm{sp}}$ and $\mathrm{BP}_{\mathrm{sp}}$ ) are reported in Table 2 .

Although the Arrhenius temperature dependence of BR (Fig. 2A) and BCC (Table 2) was strong, linear, and highly significant, we observed a more complex temperature dependence of $\mathrm{BP}$, with a highly significant Arrhenius relationship $[\log (\mathrm{BP})=-6863 \times 1 / K+24.2$; $\left.\mathrm{r}^{2}=0.37 ; F=38.7 ; \mathrm{n}=68 ; \mathrm{p}<0.0001\right)$ at lower temperatures (i.e. $<20^{\circ} \mathrm{C}$ ) and no significant relationship at temperatures above this range (Fig. 2B, Table 2). As a result of a drop in production at relatively high temperatures (Fig. 3), both Arrhenius and semi-log temperature relationships for BP were parabolic across the full temperature range, as described by 2nd order polynomial equations (Figs. 2B \& 4). Setting the first derivative of this polynomial equation equal to zero, we estimated the maximum at which BP no longer increases and begins to decrease with temperature to be approximately $22^{\circ} \mathrm{C}$ (Fig. 4). Identical analysis of the composite literature dataset revealed a similar maximum for BP of $\sim 21^{\circ} \mathrm{C}$ (Fig. 5).

The significant difference in the temperature response of $\mathrm{BP}$ and $\mathrm{BR}$ resulted in a negative temperature dependence of BGE when the full annual temperature range was considered (Fig. 6A), with higher values generally recorded in winter $(>0.5)$ and lower values in summer $(<0.2)$. Although the temperature response of BGE over the full annual temperature range could accurately be described as linear (Fig. 6A), it is important to note the discontinuous change in slope of the BGE versus temperature relationship that occurs at $\sim 22^{\circ} \mathrm{C}$ (Fig. 6B). At temperatures above this point, the negative temperature dependence of BGE was stronger and highly significant $\left(\mathrm{r}^{2}=0.23 ; \mathrm{p}<\right.$
0.0001), whereas, at lower temperatures, the relationship was weaker and marginally significant $\left(\mathrm{r}^{2}=0.09\right.$; $\mathrm{p}=0.02$ ).

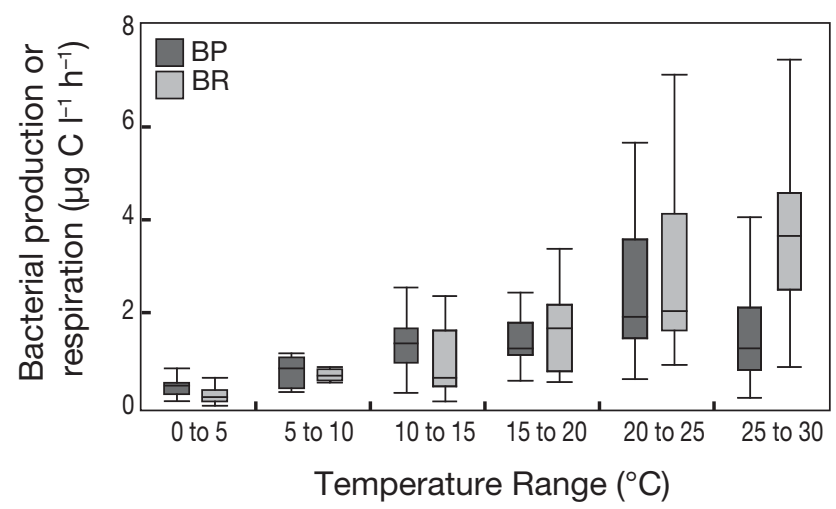

Fig. 3. Box and whisker plots of median bacterial production (BP) and respiration (BR) at discrete temperature ranges throughout the year. Quartiles represented are 10, 25, 75, and $90 \%$

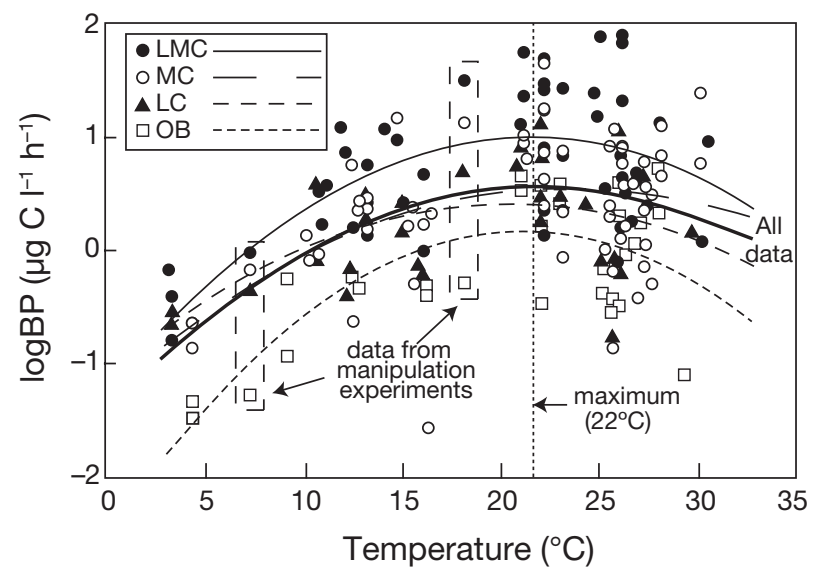

Fig. 4. Relationship between bacterioplankton production (BP) and temperature in each of the estuarine sub-systems of Monie Bay (i.e. LMC: Little Monie Creek; MC: Monie Creek; LC: Little Creek; OB: open bay). The inflection point of the second order polynomial describing the temperature response of the entire dataset (i.e. $22^{\circ} \mathrm{C}$ ) is indicated by the vertical dotted line. Data from temperature manipulation experiments are indicated by enclosures

Table 2. Regression statistics for the relationship between temperature and bacterioplankton metabolic processes. All biological parameters are log transformed except BGE. BR: bacterial respiration; BP: bacterial production; BCC: bacterial carbon consumption $[\mathrm{BP}+\mathrm{BR}]$; $\mathrm{BGE}$ : bacterial growth efficiency; $\mathrm{BR}_{\mathrm{sp}}$ : cell-specific respiration; $\mathrm{BP}_{\mathrm{sp}}$ : cell-specific production; $\mathrm{BA}$ : total bacterial abundance; nr: no relationship

\begin{tabular}{|c|c|c|c|c|c|c|c|c|c|c|c|c|c|c|c|}
\hline \multirow{2}{*}{$\begin{array}{l}\text { Para- } \\
\text { meter }\end{array}$} & \multirow[b]{2}{*}{ Slope } & \multirow[b]{2}{*}{$r^{2}$} & \multirow{2}{*}{$\begin{array}{c}\text { All data } \\
\qquad F\end{array}$} & \multirow[b]{2}{*}{$\mathrm{p}$} & \multirow[b]{2}{*}{$\mathrm{n}$} & \multicolumn{5}{|c|}{0 to $15^{\circ} \mathrm{C}$} & \multirow{2}{*}{ Slope } & \multirow[b]{2}{*}{$r^{2}$} & \multirow{2}{*}{$\begin{array}{c}15 \text { to } 30^{\circ} \\
F\end{array}$} & \multirow{2}{*}{${ }^{\circ} \mathrm{C}$} & \multirow[b]{2}{*}{$\mathrm{n}$} \\
\hline & & & & & & Slope & $r^{2}$ & $F$ & $\mathrm{p}$ & $\mathrm{n}$ & & & & & \\
\hline $\mathrm{BR}$ & 0.105 & 0.66 & 277.6 & $<0.0001$ & 147 & 0.126 & 0.45 & 40.9 & $<0.0001$ & 52 & 0.087 & 0.33 & 53.8 & $<0.0001$ & 113 \\
\hline $\mathrm{BP}$ & 0.036 & 0.16 & 33.0 & $<0.0001$ & 177 & 0.073 & 0.25 & 21.1 & $<0.0001$ & 65 & 0.009 & 0.004 & 0.5 & 0.05 & 131 \\
\hline $\mathrm{BCC}$ & 0.081 & 0.60 & 212.9 & $<0.0001$ & 147 & 0.112 & 0.53 & 52.6 & $<0.0001$ & 49 & 0.057 & 0.195 & 26.8 & $<0.0001$ & 113 \\
\hline BGE & -0.014 & 0.34 & 73.3 & $<0.0001$ & 147 & -0.011 & $\mathrm{nr}$ & 4.4 & 0.05 & 52 & -0.026 & 0.37 & 60.5 & $<0.0001$ & 105 \\
\hline $\mathrm{BR}_{\mathrm{sp}}$ & 0.079 & 0.35 & 74.8 & $<0.0001$ & 139 & 0.137 & 0.34 & 21.7 & $<0.0001$ & 45 & 0.036 & 0.04 & 4.2 & 0.043 & 109 \\
\hline $\mathrm{BP}_{\mathrm{sp}}$ & 0.015 & 0.03 & 4.1 & 0.04 & 169 & 0.091 & 0.27 & 20.9 & $<0.0001$ & 58 & -0.030 & 0.03 & 4.1 & 0.046 & 127 \\
\hline $\mathrm{BA}$ & 0.018 & 0.06 & 8.6 & 0.004 & 139 & 0.002 & $<0.001$ & $<0.01$ & 0.9 & 43 & 0.054 & 0.2 & 27.0 & $<0.0001$ & 109 \\
\hline
\end{tabular}




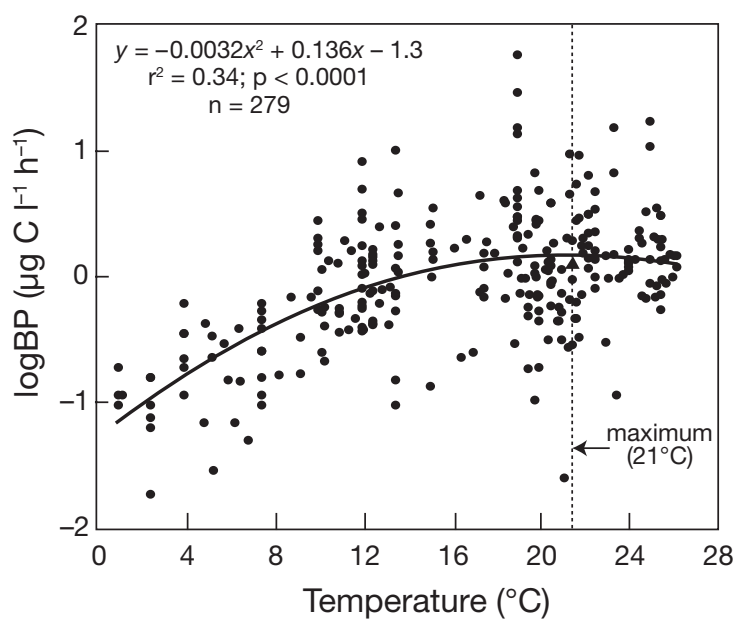

Fig. 5. Relationship between bacterioplankton production (BP) and temperature revealed by a composite literature dataset representing different estuarine systems, including Chesapeake Bay, Choptank River, Delaware Bay, Long Island Sound, Roskilde Fjord, St. Lawrence River, and Urdaibai Estuary. See 'Materials and methods' for references. The inflection point of the curve is indicated by the vertical dotted line

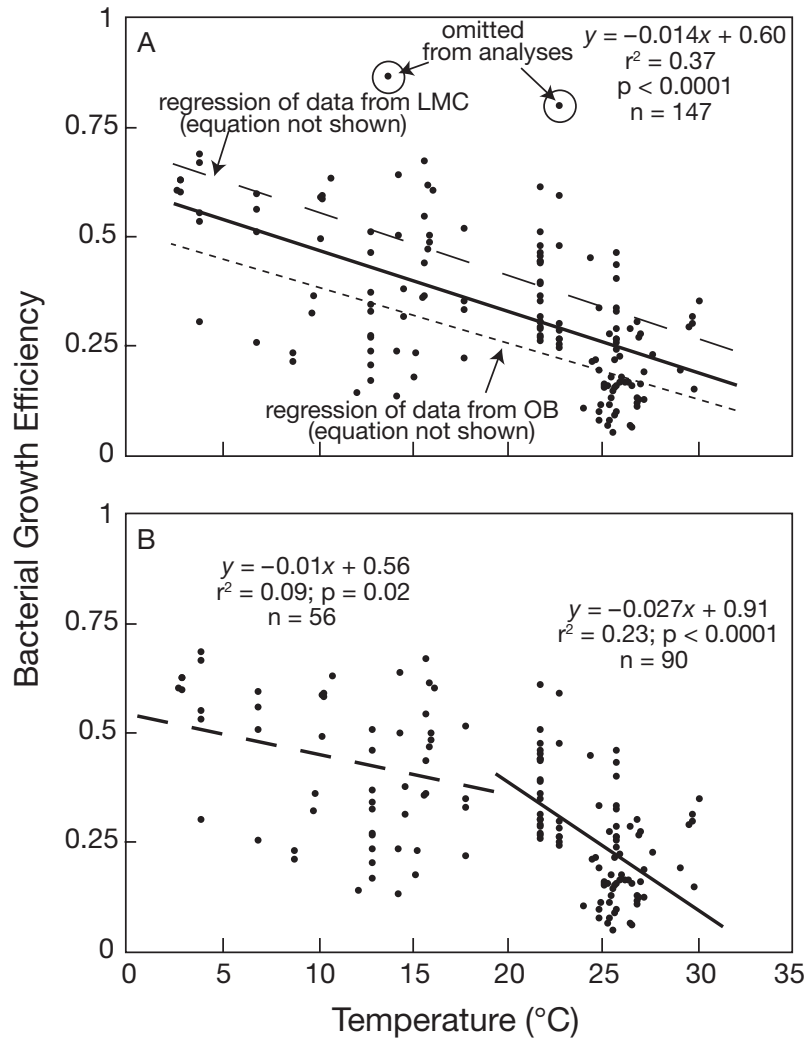

Fig. 6. Linear relationships between bacterial growth efficiency and temperature for (A) the entire dataset and (B) warmer versus colder ambient water temperatures. In A, bestfit lines for regressions of data from Little Monie Creek (LMC) and the open bay (OB) are indicated by broken lines; solid line represents regression of all data
Combining log-transformed rates for BP and BR with bacterial abundance and replotting these data versus temperature (Fig. 7A) revealed that patterns in the temperature dependence of $\mathrm{BP}_{\mathrm{sp}}$ and $\mathrm{BR}_{\mathrm{sp}}$ were similar to those of their community-level counterparts (Fig. 7B), with a significant difference in temperature response of both $\mathrm{BP}_{\mathrm{sp}}$ and $\mathrm{BR}_{\mathrm{sp}}$ (ANCOVA: $\mathrm{r}^{2}=0.30$; $\mathrm{n}=308 ; F=32.8 ; \mathrm{p}<0.0001$ ) that resulted in higher $\mathrm{BR}_{\mathrm{sp}}$ than $\mathrm{BP}_{\mathrm{sp}}$ at temperatures above approximately $20^{\circ} \mathrm{C}$. A comparison of mean abundance at low and high temperatures revealed a small increase from 9.2 to $9.5 \times 10^{6}$ cells $\mathrm{ml}^{-1}$, although regression of abundance versus metabolic rate revealed that the contribution of this change to total variability in $\mathrm{BP}_{\mathrm{sp}}$ or $\mathrm{BR}_{\mathrm{sp}}$ was relatively small (i.e. $\mathrm{r}^{2}=0.24$ and 0.36 , respectively).

Temperature responses for all metabolic processes measured at lower $\left(0\right.$ to $\left.15^{\circ} \mathrm{C}\right)$ versus higher $(15$ to $30^{\circ} \mathrm{C}$ ) temperature ranges were compared using both the slope of semi-log plots (Table 2) and $Q_{10}$ values (Table 3). In general, the effect of temperature on bacterioplankton carbon metabolism was greatest at lower temperatures, as evidenced by higher correlation coefficients, steeper slopes, and higher $Q_{10}$ values for the 0 to $15^{\circ} \mathrm{C}$ temperature range. This pattern was particu-
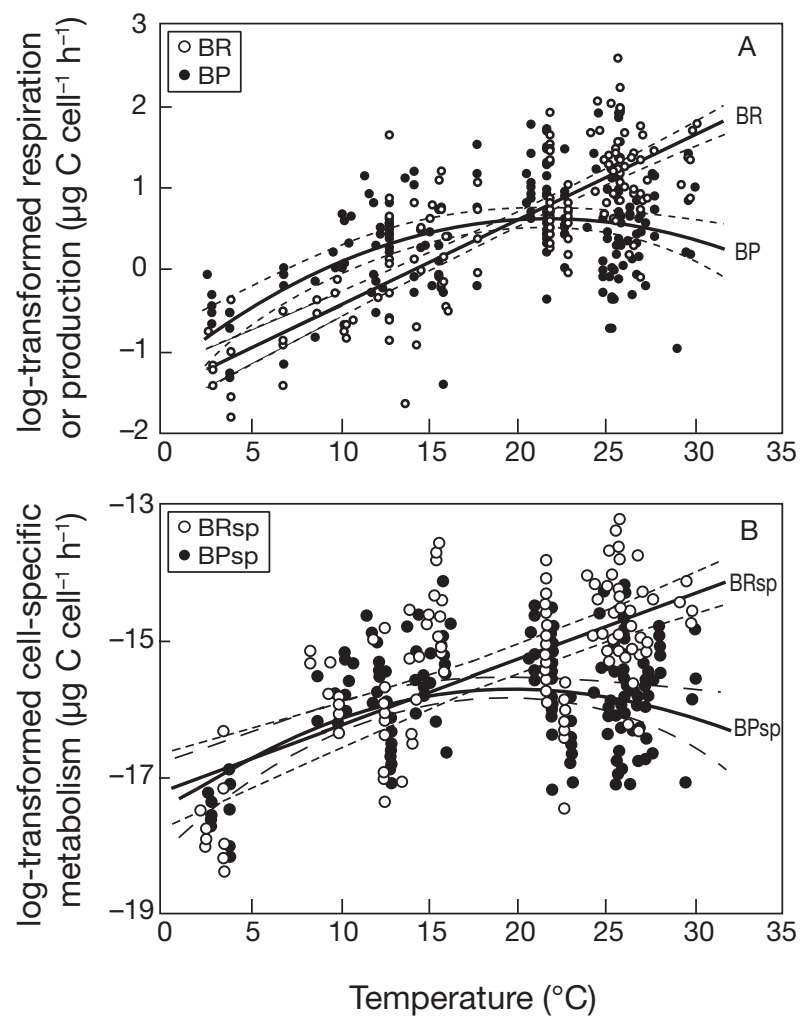

Fig. 7. Comparison of the temperature dependence of (A) bacterioplankton respiration (BR) and production (BP) and (B) cell-specific respiration $\left(\mathrm{BR}_{\mathrm{sp}}\right)$ and cell-specific production $\left(\mathrm{BP}_{\mathrm{sp}}\right)$. Broken lines represent $95 \%$ confidence intervals 
Table 3. Estimates of $Q_{10}$ values for measures of bacterial metabolism calculated at different temperature ranges: $Q_{10}=$ $\left(R_{1} / R_{2}\right)^{10 /\left(T_{1}-T_{2}\right)}$. Parameters defined in Table 2

\begin{tabular}{|lrrr|}
\hline Parameter & $<15^{\circ} \mathrm{C}$ & $>15^{\circ} \mathrm{C}$ & 0 to $30^{\circ} \mathrm{C}$ \\
\hline BR & 3.8 & 2.2 & 1.6 \\
BP & 1.3 & 1.1 & 1.4 \\
BCC & 3.0 & 1.8 & 2.3 \\
BR $_{\text {sp }}$ & 3.9 & 1.4 & 4.4 \\
BP $_{\text {sp }}$ & 2.5 & -1.0 & 1.2 \\
Mean & 3.0 & 1.1 & 2.2 \\
BGE & -1.3 & -3.6 & -1.5 \\
\hline
\end{tabular}

larly strong for BR, with an almost 2-fold higher effect of temperature at colder versus warmer temperatures for both $\mathrm{BR}$ and $\mathrm{BR}_{\mathrm{sp}}$. The temperature dependence of BP decreased with increasing temperature, although this shift was not as dramatic and the relationship was weaker than that exhibited by respiration. Likewise, the temperature dependence of cell-specific metabolism was significantly stronger for the lower half of the annual temperature range (Table 2).

We observed significant differences in the magnitude of most measured metabolic processes at any given temperature when the different sub-systems were compared. The $y$-intercepts (of log metabolism versus temperature) for $\mathrm{BP}, \mathrm{BCC}$, and $\mathrm{BGE}$ differed significantly among the sub-systems (Table 4), with highest values consistently observed in the nutrientenriched tidal creek (LMC), lowest in the open bay, and intermediate at the less-enriched LC and freshwater-influenced MC sites. In particular, BP had significantly ( $p<0.0001$ ) higher and lower $y$-intercepts for LMC and OB, respectively, when compared to MC and LC (Fig. 4). Intercepts for MC and LC were statistically similar and did not differ from the overall $y$-intercept for the composite dataset. The same pattern was observed for $\mathrm{BGE}$, represented by the regressions in Fig. 6A (broken lines). ANCOVAs (Table 4) revealed that significant but independent effects of both subsystem and temperature were also observed with BCC

Table 4. Probability values from ANCOVA with temperature $\left(0\right.$ to $\left.30^{\circ} \mathrm{C}\right)$ and sub-system (Little Monie Creek, Monie Creek, Little Creek and open bay) as model effects. Parameters defined in Table 2

\begin{tabular}{|c|c|c|c|c|c|}
\hline \multirow[t]{2}{*}{ Parameter } & \multirow[b]{2}{*}{ Temperature } & \multirow{2}{*}{$\begin{array}{c}\text { Model effects } \\
\text { Sub-system }\end{array}$} & \multirow[b]{2}{*}{ Interaction } & \multirow[t]{2}{*}{$r^{2}$} & \multirow[t]{2}{*}{$\mathrm{n}$} \\
\hline & & & & & \\
\hline $\mathrm{BR}$ & $<0.0001$ & 0.08 & 0.9 & 0.65 & 129 \\
\hline $\mathrm{BP}$ & $<0.0001$ & $<0.0001$ & 0.8 & 0.34 & 169 \\
\hline BP (filtered) & $<0.0001$ & 0.0004 & 0.7 & 0.23 & 169 \\
\hline $\mathrm{BCC}$ & $<0.0001$ & 0.0002 & 0.8 & 0.63 & 139 \\
\hline BGE & $<0.0001$ & 0.004 & 0.3 & 0.39 & 129 \\
\hline $\mathrm{BR}_{\mathrm{sp}}$ & $<0.0001$ & 0.8 & 0.7 & 0.36 & 139 \\
\hline $\mathrm{BP}_{\mathrm{sp}}$ & $<0.0001$ & 0.002 & 0.7 & 0.17 & 129 \\
\hline
\end{tabular}

$\left(\mathrm{p}<0.0001 ; \mathrm{r}^{2}=0.66 ; \mathrm{df}=146 ; F=38.2\right)$ and BGE $(\mathrm{p}<$ 0.0001 and $\mathrm{p}=0.004$, respectively; $\mathrm{r}^{2}=0.41$; $\mathrm{df}=146$; $F=1.8$ ). The temperature response of BR was the least variable, with statistically similar slopes and $y$-intercepts among all sub-systems (ANCOVA: $\mathrm{r}^{2}=0.65 ; \mathrm{n}=$ 139; $\mathrm{p}<0.0001)$. We found no significant interaction of temperature and environmental conditions when BCC and BGE were considered $(p=0.8$ and 0.3 , respectively).

A comparison of carbon metabolism in similar temperature regimes (i.e. 14 to $16^{\circ} \mathrm{C}$ and 21 to $22^{\circ} \mathrm{C}$ ), but in different seasons (i.e. spring vs. fall) revealed that BP was always higher in spring than in fall when samples of similar temperature were compared. In the 21 to $22^{\circ} \mathrm{C}$ temperature range, mean BP of samples collected in June 2000 and May 2001 was significantly higher than that in September 2000 (Student's $t$-test: $t=1.7$; $\mathrm{df}=28 ; \mathrm{p}<0.1$ ) and samples in the 14 to $16^{\circ} \mathrm{C}$ range collected during April 2001 were also significantly higher when compared to October 2001 (Student's $t$-test: $t=1.7 ; \mathrm{df}=18 ; \mathrm{p}<0.07)$. Although BP was different between spring and fall in each temperature regime, significant differences in BGE were only observed in the lower temperature range (Student's $t$-test: $t=4.2 ; \mathrm{df}=13 ; \mathrm{p}<0.05$ ) and there was no difference in the magnitude of BR between the 2 seasons at similar in situ temperatures ( $\mathrm{n}=20$ and 40, respectively; data not shown).

\section{DISCUSSION}

\section{Temperature dependence among measures of carbon metabolism}

Significantly different slopes in Arrhenius plots indicate that bacterioplankton production and respiration respond differently to changes in temperature and suggest that this may be attributed to differences in the activation energy associated with these metabolic processes (Zumdahl 1989). For example, the lower slope of the BP regressions indicates a lower activation energy required for this process relative to that of BR. This difference in activation energy is not surprising, for although growth and respiration are inherently coupled (del Giorgio \& Cole 2000), BP and BR are the measured endpoints of numerous and distinct biochemical and physiological processes, each with its own temperature dependence (Rose 1967, Morita 1974). The negative temperature dependence of BGE produced by the significant difference in temperature response of $\mathrm{BP}$ and 
BR is strikingly similar to that reported by Daneri et al. (1994) in their study of BGE in marine enclosures $\left(\mathrm{BGE}=-0.017 \times \mathrm{TEMP}+0.52 ; \mathrm{r}^{2}=0.35 ; \mathrm{p}<0.0001\right)$ and to that calculated by Rivkin \& Legendre (2001) in their review of $\mathrm{BGE}$ in marine systems $(\mathrm{BGE}=-0.011 \times$ TEMP $\left.+0.37 ; \mathrm{r}^{2}=0.54 ; \mathrm{p}<0.0001\right)$. Studies conducted in sub-arctic marine sediments (Griffiths et al. 1984) and on both mixed seawater and pure cultures (Tison \& Pope 1980, Bjørnsen 1986) also report a negative effect of temperature on BGEs. However, the importance of temperature in regulating BGE is not revealed in the findings of all studies on growth efficiency, many of which identify organic matter supply and quality (del Giorgio \& Cole 1998, Jørgensen et al. 1999, Reinthaler \& Herndl 2005) and dissolved nutrient stoichiometry (Goldman et al. 1987, Kroer 1993) as the most important factors responsible for the regulation of BGE in coastal and estuarine systems.

Because the combined effects of temperature and resource supply may not always be apparent in studies encompassing a relatively narrow temperature range or that compare systems of similar enrichment, such discrepancies in the literature are to be expected. This lack of consensus does not necessarily represent a conflict, rather it suggests that both temperature and resource supply exert a simultaneous influence on the magnitude and variability of BGE in temperate systems. In this regard, our 2 yr study reveals that temperature drives changes in the magnitude of BGE throughout the year, whereas resources account for differences in magnitude at any given temperature or between systems differing in their degree of enrichment. Our results also provide evidence that resource limitation and adverse effects of elevated temperatures may combine to produce decreases in BGE during summer months.

\section{Temperature dependence at high versus low temperature range}

The temperature dependence of a metabolic process is conventionally defined by an exponential relationship, which is linearized using an Arrhenius plot (Pomeroy et al. 2000). However, not all in situ metabolic processes respond to temperature changes in this manner, and such monotonic relationships may not be appropriate for describing temperature dependence across wide temperature ranges. For example, comparison of the temperature response (i.e. $Q_{10}$ ) for all metabolic processes in lower versus higher temperature ranges revealed that the effect of temperature was greatest at lower temperatures - a finding that corroborates studies of respiration in marine bacterioplankton (Pomeroy \& Deibel 1986) and lake bacterioplankton and sediments (den Heyer \& Kalff
1998, Carignan et al. 2000). Similarly, our observation of elevated temperature dependence of $\mathrm{BP}_{\mathrm{sp}}$ at lower temperatures was almost identical to that reported for nonsummer months in temperate estuaries similar to that of Monie Bay (Hoch \& Kirchman 1993, Shiah \& Ducklow $1994 a, b)$. Additional evidence that not all temperature responses are linear is provided by a comparison of the strong, linear, and highly significant temperature response of $\mathrm{BR}$ and $\mathrm{BCC}$ relative to that of $\mathrm{BP}$, which exhibited a parabolic Arrhenius relationship, with a maximum of approximately $22^{\circ} \mathrm{C}$. This maximum value was corroborated by our analysis of a composite dataset representing studies in a wide range of temperate estuaries (Fig. 5). The existence of these maximum values is consistent with the non-linear temperature response and temperature optima observed for the specific growth rate of temperate brackish water bacterioplankton $\left(20^{\circ} \mathrm{C}\right)$ and cold-water isolates (20 to $25^{\circ} \mathrm{C}$; Autio 1992).

The significant negative linear relationship between BGE and temperature observed in our study and described by others (Daneri et al. 1994, Rivkin \& Legendre 2001) implies that growth efficiency exhibits a consistent and linear decrease with increasing water temperatures. However, there is a precipitous decrease in the magnitude of BGE at temperatures above approximately $22^{\circ} \mathrm{C}$, revealing that the assumption of a linear temperature response may not accurately describe changes in BGE in natural aquatic systems. Similar decreases in BGE with temperature have been reported elsewhere (Tison \& Pope 1980, Griffiths et al. 1984, Bjørnsen 1986, Cowan \& Boynton 1996). Several explanations exist for this non-linear response of growth efficiency over wide temperature ranges. The difference in temperature response of BP and BR that drives this relationship may be attributed to the direct effect of temperature on cellular-level processes, as substantive increases in the ratio of $\mathrm{BR}_{\mathrm{sp}}$ to $\mathrm{BP}_{\mathrm{sp}}$ at temperatures $>20^{\circ} \mathrm{C}$ have been observed in cultured bacteria (Rose 1967). Such direct physiological effects of temperature on bacterioplankton might include a disproportionate increase in energetic demands of anabolic processes at higher temperatures (Caron et al. 1990) or physiological stress associated with supraoptimal ambient water temperatures (Sherr \& Sherr 1996). Temperature-dependent changes in membrane composition may influence the affinity of transport proteins for organic matter substrates, resulting in a change in the efficiency with which these proteins operate and with which bacterial growth occurs (Nedwell 1999). Apparent changes in BP may also result as an artifact of temperature-driven changes in the relationship between carbon production and leucine incorporation (Tibbles 1996). Alternatively, recent studies conducted in temperate lakes (Coveney \& Wetzel 1995, Carlsson \& Caron 2001) and estuaries (Hoch \& 
Kirchman 1993, Shiah \& Ducklow 1994a, Raymond \& Bauer 2000) might suggest that this pattern is driven by a community-level response, in which the weakening of bacterioplankton growth response above 15 to $20^{\circ} \mathrm{C}$ is attributed to a shift from temperature to resource limitation, whereby BP and BG would be released from temperature constraints as a result of the strong nutrient and carbon limitation that occurs during warmer months (Shiah \& Ducklow 1994a, Coveney \& Wetzel 1995, Felip et al. 1996).

Given the shifts in temperature dependence observed for different metabolic processes and temperature ranges, it would be naïve to assume uniform temperature response functions for $\mathrm{BP}, \mathrm{BR}$, and other metabolic processes. Although the overall mean $Q_{10}$ for our measured rates of carbon metabolism across the annual temperature range (Table 3 ) was similar to the commonly used $Q_{10}$ of 2 (Toolan 2001, del Giorgio \& Davis 2003), mean $Q_{10}$ values for high and low temperature ranges were 1.1 and 3.0, respectively, indicating that the assumption of constant temperature dependence would tend to cause temperature responses to be underestimated at low temperatures and overestimated at higher temperatures. Despite the substantial annual variability in water temperatures of temperate estuaries, conventional models of microbial dynamics tend to employ highly simplified formulations for temperature dependence of bacterioplankton carbon metabolism (Ducklow 1994, Davidson 1996). Consequently, models assuming a fixed value for BGE throughout the year may provide inaccurate estimates of microbially mediated carbon flux for the aquatic systems they are meant to represent.

\section{Temperature dependence and magnitude of carbon metabolism among different systems}

As detailed by previous work in this system (Apple et al. 2004), the tributaries of Monie Bay exhibit significant systematic differences in many environmental conditions. Despite these environmental differences, we found no significant difference in the effect of temperature (i.e. slope of log metabolism versus temperature function) on measures of carbon metabolism among the 4 sub-systems (Table 4). Although one might predict that temperature and environmental conditions interact to regulate the seasonal patterns in BGE and BCC (Pomeroy \& Wiebe 2001), we found no significant interaction of these parameters when BGE and BCC were considered.

The robust nature of temperature dependence and systematic patterns in the magnitude of carbon metabolism was confirmed by our temperature manipulation experiments, where $\mathrm{BP}$ and $\mathrm{BR}$ were measured at ambient $\left(18^{\circ} \mathrm{C}\right)$ and reduced $\left(7^{\circ} \mathrm{C}\right)$ water temperatures. This experiment, designed to investigate the direct effect of temperature on bacterioplankton carbon metabolism, revealed that rates of BP and BR at ambient and manipulated temperatures, not only conformed to the temperature dependencies expected based on regression models, but also exhibited the same rank-order among sub-systems that was observed previously in this system and that corresponds to system-level enrichment (Figs. 2 \& 4, Table 1; Apple et al. 2004), with highest rates recorded in $\mathrm{LMC}$, intermediate in $\mathrm{MC}$ and LC, and lowest in OB. These significant differences in $y$-intercepts and near perfectly parallel lines or similar slope functions for each sub-system (Fig. 4) would suggest that there is a strong environmental component regulating bacterioplankton growth and production that persists throughout the year and is independent of temperature. In contrast, the lack of significant differences in either the slopes or the intercepts of the BR versus temperature relationship would suggest that temperature is the main overriding control of respiration in these systems. This pattern also suggests that the environmental factors varying among these tidal creek systems either do not have a strong regulatory effect on $\mathrm{BR}$ or are at concentrations that do not result in limitation. This primacy of temperature in regulating respiration in the presence of variability of other environmental conditions has also been observed for the mainstem Chesapeake Bay (Sampou \& Kemp 1994), where effects of temperature on both bacterioplankton and total community respiration were identical for field measurements and temperature manipulation experiments, despite being accompanied by seasonal changes in nutrient status. Based on these observations, we concluded that temperature regulates the magnitude of carbon metabolism on a relatively coarse scale throughout the year, while finer-scale variability at any given temperature is attributed to local environmental conditions. Furthermore, the effect of temperature is most pronounced with $\mathrm{BR}$ and $\mathrm{BCC}$, which appear to be regulated almost exclusively by temperature in this carbon-rich system of tidal creeks. In contrast, although BP experiences significant effects of temperature at lower temperatures, the magnitude of BP and BGE may be more heavily influenced by nutrient availability or the quality of dissolved organic matter (DOM).

In a study of lake bacterioplankton, Felip et al. (1996) present a conceptual model illustrating hypothetical changes in bacterioplankton growth as a function of temperature among 4 aquatic systems differing in their degree of nutrient enrichment. Their conceptual model (Fig. 7 in Felip et al. 1996) depicts a temperature response that is strikingly similar to the generally curvilinear response in growth observed across the annual temperature range of our study, as well as a pre- 
dictable rank-order in magnitude among the 4 subsystems (Fig. 4). As predicted by the authors, we found that bacterioplankton growth and production exhibited strong temperature dependence below a certain threshold (i.e. $\sim 22^{\circ} \mathrm{C}$ for production [Figs. 5 \& 7] and $20^{\circ} \mathrm{C}$ for growth [Fig. 6]) and a rank-order in magnitude that reflects the degree of enrichment and resource supply. Whereas these authors predict a plateau in growth above this threshold, we observed a decline in production and growth at higher temperatures. Thus, although the conceptual model of Felip et al. (1996) may accurately describe the temperature response of lake and estuarine bacterioplankton at lower temperatures with respect to the rank-order of systems differing in degree of enrichment, our study provides the additional insight that growth and production decline rather than reaching a plateau at elevated temperatures. The observation of similar resource-driven rank-orders among systems in both tidal creeks and lakes suggests that this combined response to temperature and resource supply may represent a transferable characteristic of microbial communities among temperate aquatic systems.

\section{Combined effects of temperature and resource supply in warmer months}

It is difficult to determine if the maximum of $\sim 22^{\circ} \mathrm{C}$ calculated for BP and the decrease in BGE above $20^{\circ} \mathrm{C}$ represents a physiological optimum temperature above which elevated temperatures have an adverse effect on bacterioplankton production (Autio 1992) or the direct effect of limitations on growth imposed by other environmental factors encountered during summer months (Shiah \& Ducklow 1994a, Coveney \& Wetzel 1995). The almost identical decrease of BP at elevated temperatures and persistent rank-order of $\mathrm{BP}$ among the 4 sub-systems suggests the influence of an environmental factor more universal than resource supply and quality, as these vary greatly among the 4 sub-systems (Table 1), thus supporting the fundamental role of temperature in the decline of BP and BGE. However, although annual mean concentrations of nutrients differ systematically among our 4 study sites, high assimilative demand (e.g. marsh plants, benthic algae) throughout the summer keeps nutrients at physiologically low concentrations (Jones et al. 1997), with summer values for all sites at or below typical values for algal kinetic half-saturation coefficients (e.g. $\mathrm{NH}_{4}^{+}$ $<2 \mu \mathrm{M}, \mathrm{PO}_{4}{ }^{3-}<0.2 \mu \mathrm{M}$; Apple 2005) and thereby potentially limiting for bacterioplankton growth. Thus, although adverse effects of elevated temperatures on bacterioplankton metabolism have been reported (Sherr \& Sherr 1996) and are implicit in the tempera- ture response of BP in this and other systems (Figs. 4 \& 5), we acknowledge that the decrease in BP and BGE during summer months may be attributed in part to seasonal changes in nutrient availability or the supply and quality of DOM substrates (Pomeroy et al. 1995). This was investigated by comparing rates of carbon metabolism in similar temperature regimes (i.e. 14 to 16 and 21 to $22^{\circ} \mathrm{C}$ ), but different seasons (i.e. spring vs. fall), functionally keeping temperature constant, while other environmental factors were allowed to fluctuate.

Availability of DOM was quickly ruled out as a factor limiting carbon metabolism in this system, as BP versus ambient dissolved organic carbon concentrations were not correlated (data not reported) and BR increased consistently across the entire temperature range and did not differ in magnitude between the 2 seasons at similar in situ temperatures. Thus, environmental factors other than temperature that are responsible for decreases in BP would probably include either DOM quality or dissolved nutrient availability. Ambient nutrient concentrations were significantly higher in spring than at comparable temperatures during fall (Apple 2005), a pattern which was reflected in BP at both temperature ranges and BGE at only the highest $\left(21\right.$ to $22^{\circ} \mathrm{C}$ ). Although this suggests a direct response to dissolved nutrients, the rank order in BP and BGE among systems more closely reflects differences in the DOM source, and we predict that aspects of organic matter quality (e.g. nutrient content) have a more important effect than dissolved nutrients alone on BP and BGE. With respect to BGE, this among-season difference combined with a precipitous decrease in BGE and the obfuscation of among-system differences at temperatures $>20^{\circ} \mathrm{C}$ (Fig. 5) provide evidence that there may be a point between 16 and $21^{\circ} \mathrm{C}$ at which the regulation of $\mathrm{BGE}$ shifts from resource to temperature. We conclude that BR is regulated almost exclusively by temperature regardless of other environmental conditions, whereas BP and BGE are influenced by both temperature and organic matter quality and that effects of these factors are simultaneous, non-interacting, and change in importance throughout the year.

\section{CONCLUSIONS}

Our research reveals that bacterioplankton carbon metabolism exhibits significant temperature dependence and that this temperature dependence varies among different measures of carbon metabolism and throughout the annual temperature cycle. The temperature response of BR is strong (high $\mathrm{r}^{2}$ ), has a relatively steep slope, a log-linear response across the annual temperature range, and a similar slope and intercept among the different estuarine sub-systems. The relationship be- 
tween BP and temperature, on the other hand, is characterized by much lower $\mathrm{r}^{2}$ values, a curvilinear response, and significantly different intercepts for sub-systems differing in degree of resource enrichment. Respiration is the metabolic process that is most directly influenced by temperature, whereas environmental factors such as nutrient availability and DOM quality may play a much larger role in regulating the magnitude of BP. Thus, although the basic temperature control of BCC appears to be similar in all systems, the influence of temperature on BP appears to be strongly modulated by local environmental conditions. As a consequence, systems that follow the same basic seasonal progression in BR and BCC may differ substantially in terms of bacterial biomass production, growth, and growth efficiencies and thus differ in how organic matter is processed.

Our study has provided novel insight into the temperature dependence of bacterioplankton carbon metabolism in estuarine systems, yet the mechanisms underlying many of the observed patterns remain poorly understood. For example, our study suggests that decreases in BP and BGE at temperatures above $\sim 22^{\circ} \mathrm{C}$ may be a universal property of temperate estuaries and, although we predict this result from the combined effects of supra-optimal temperatures and seasonal changes in resource quality, the extent to which each of these factors individually and/or collectively influences BP and BGE in summer months is not known. Also unclear is the extent to which patterns in the temperature response of BP may actually reflect temperature-dependent changes in leucine-to-carbon conversion factors. Further investigation of these questions is necessary to improve our understanding of the mechanisms underlying patterns in the magnitude and annual variability of bacterioplankton carbon metabolism in temperate estuaries.

Acknowledgements. This research was funded in part by a graduate research fellowship awarded by the National Estuarine Research Reserve System and by a grant from the Cooperative Institute for Coastal and Estuarine Environmental Technology. We thank the panel of anonymous reviewers for their time, effort, and valuable contributions, as well as committee members D. Stoecker, D. Kirchman, and T. Fisher for their support, guidance, and intellectual contribution to this manuscript. This is contribution number 3971 for the University of Maryland Center for Environmental Science.

\section{LITERATURE CITED}

Anderson TH, Taylor GT (2001) Nutrient pulses, plankton blooms, and seasonal hypoxia in western Long Island Sound. Estuaries 24:228-243

Apple JK (2005) The regulation of bacterioplankton metabolism in a temperate salt-marsh estuary. PhD dissertation, University of Maryland, Cambridge, MD

Apple JK, del Giorgio PA, Newell RIE (2004) The effect of system-level nutrient enrichment on bacterioplankton production in a tidally-influenced estuary. J Coast Res 45: $110-133$

Autio RM (1992) Temperature regulation of brackish water bacterioplankton. Hydrobiologia 37:253-263

Bjørnsen PK (1986) Bacterioplankton growth-yield in continuous seawater cultures. Mar Ecol Prog Ser 30:191-196

Bjørnsen PK, Riemann B, Pock-Steen J, Nielsen TG, Horsted SJ (1989) Regulation of bacterioplankton production and cell volume in a eutrophic estuary. Appl Environ Microbiol 55:1512-1518

Carignan R, Planas D, Vis C (2000) Planktonic production and respiration in oligotrophic Shield Lakes. Limnol Oceanogr 45:189-199

Carlsson P, Caron DA (2001) Seasonal variation of phosphorus limitation of bacterial growth in a small lake. Limnol Oceanogr 46:108-120

Caron DA, Goldman JC, Fenchel T (1990) Protozoan respiration and metabolism. In: Capriulo G (ed) Ecology of marine protozoa. Oxford University Press, New York, p 307-322

Coveney MF, Wetzel RG (1995) Biomass, production, and specific growth rate of bacterioplankton and coupling to phytoplankton in an oligotrophic lake. Limnol Oceanogr 40:1187-1200

Cowan JLW, Boynton WR (1996) Sediment-water oxygen and nutrient exchanges along the longitudinal axis of Chesapeake Bay: seasonal patterns, controlling factors, and ecological significance. Estuaries 19:562-580

Crawford CC, Hobbie JE, Webb KL (1974) The utilization of dissolved free amino acids by estuarine microorganisms. Ecology 55:551-563

Daneri G, Riemann B, Williams PJLeB (1994) In situ bacterial production and growth yield measured by thymidine, leucine and fractionated dark oxygen uptake. J Plankton Res 16:105-113

Davidson K (1996) Modeling microbial food webs. Mar Ecol Prog Ser 145:279-296

del Giorgio PA, Bouvier TC (2002) Linking the physiologic and phylogenetic successions in free-living bacterial communities along an estuarine salinity gradient. Limnol Oceanogr 47:471-486

del Giorgio PA, Cole JJ (1998) Bacterial growth efficiency in natural aquatic systems. Annu Rev Ecol Syst 29:503-541

del Giorgio PA, Cole JJ (2000) Bacterial growth energetics and efficiency in natural aquatic systems. In: Kirchman DL (ed) Microbial ecology of the oceans. Wiley \& Sons, New York, p 289-325

del Giorgio PA, Davis J (2003) Patterns in dissolved organic matter lability and consumption across aquatic ecosystems. In: Findlay S (ed) Aquatic ecosystems: interactivity of dissolved organic matter. Elsevier Science, Amsterdam, p 399-424

del Giorgio PA, Williams PJLeB (2005) Respiration in aquatic ecosystems. Oxford University Press, New York

del Giorgio PA, Bird DF, Prairie YT, Planas D (1996) Flow cytometric determination of bacterial abundance in lake plankton using the green nucleic acid stain SYTO 13. Limnol Oceanogr 41:783-789

den Heyer C, Kalff J (1998) Organic matter mineralization rates in sediments: a within- and among-lake study. Limnol Oceanogr 43:695-705

Ducklow HW (1994) Modeling the microbial food web. Microb Ecol 28:303-319

Felip M, Pace ML, Cole JJ (1996) Regulation of planktonic bacterial growth rates: the effects of temperature and resources. Microb Ecol 31:15-28

Goldman JC, Caron DA, Dennet MR (1987) Regulation of 
gross growth efficiency and ammonium regeneration in bacteria by C:N ratio. Limnol Oceanogr 32:1239-1252

Griffiths R, Caldwell B, Morita RY (1984) Observations on microbial percent respiration values in arctic and subarctic marine waters and sediments. Microb Ecol 10:151-164

Hoch MP, Kirchman DL (1993) Seasonal and inter-annual variability in bacterial production and biomass in a temperate estuary. Mar Ecol Prog Ser 98:283-295

Iturriaga R, Hoppe HG (1977) Observations of heterotrophic activity on photoassimilated organic matter. Mar Biol 40: 101-108

Jahnke RA, Craven DB (1995) Quantifying the role of heterotrophic bacteria in the carbon cycle: a need for respiration rate measurements. Limnol Oceanogr 40:436-441

Jones TW, Murray L, Cornwell JC (1997) A two-year study of the short-term and long-term sequestering of nitrogen and phosphorus in the Maryland National Estuarine Research Reserve. Maryland National Estuarine Research Reserve, Monie Bay, MD

Jørgensen N, Kroer N, Coffin RB, Hoch MP (1999) Relations between bacterial nitrogen metabolism and growth efficiency in an estuarine and an open-water ecosystem. Aquat Microb Ecol 18:247-261

Kana TM, Darkangelo C, Hunt MD, Oldham JB, Bennet GE, Cornwell JC (1994) Membrane inlet mass-spectrometer for rapid high-precision determination of $\mathrm{N}_{2}, \mathrm{O}_{2}$, and $\mathrm{Ar}$ in environmental water samples. Anal Chem 66:4166-4170

Kirchman DL (1993) Leucine incorporation as a measure of biomass production by heterotrophic bacteria, Chapter 58 . In: Kemp PF, Sherr BF, Sherr EB, Cole JJ (eds) Handbook of methods in aquatic microbial ecology. CRC Press, Boca Raton, FL, p 509-512

Kroer N (1993) Bacterial-growth efficiency on natural dissolved organic matter. Limnol Oceanogr 38:1282-1290

Lee CW, Kudo I, Yokokawa T, Yanada M, Maita Y (2002) Dynamics of bacterial respiration and related growth efficiency, dissolved nutrients and dissolved oxygen concentration in a subarctic coastal embayment. Mar Freshw Res 53:1-7

Madigan MT, Martinko JM, Parker J (2003) Brock biology of microorganisms. Prentice Hall, Upper Saddle River, NJ

Morita RY (1974) Temperature effects on marine microorganisms. In: Colwell RR, Morita RY (eds) Effect of the ocean environment on microbial activities. University Park Press, Baltimore, MD, p 75-79

Nedwell DB (1999) Effect of low temperature on microbial growth: lowered affinity for substrates limits growth at low temperature. FEMS Microbiol Ecol 30:101-111

Pomeroy LR, Deibel D (1986) Temperature regulation of bacterial activity during the spring bloom in Newfoundland coastal waters. Science 233:359-361

Pomeroy LR, Wiebe WJ (2001) Temperature and substrates as interactive limiting factors for marine heterotrophic bacteria. Aquat Microb Ecol 23:187-204

Pomeroy LR, Wiebe WJ, Deibel D, Thompson RJ, Rowe GT, Pakulski JD (1991) Bacterial responses to temperature and substrate concentration during the Newfoundland spring bloom. Mar Ecol Prog Ser 75:143-159

Pomeroy LR, Sheldon JE, Sheldon WM, Peters F (1995) Limits to growth and respiration of bacterioplankton in the Gulf of Mexico. Mar Ecol Prog Ser 117:259-268

Pomeroy LR, Sheldon JE, Sheldon WM, Blanton JO, Amft J, Peters F (2000) Seasonal changes in microbial processes in estuarine and continental shelf waters of the southeastern

Editorial responsibility: Lars Tranvik,

Uppsala, Sweden
USA. Estuar Coast Shelf Sci 51:415-428

Ram ASP, Nair S, Chandramohan D (2003) Bacterial growth efficiency in the tropical estuarine and coastal waters of Goa, southwest coast of India. Microb Ecol 45:88-96

Raymond PA, Bauer JE (2000) Bacterial consumption of DOC during transport through a temperate estuary. Aquat Microb Ecol 22:1-12

Reay DS, Nedwell DB, Priddle J, Ellis-Evans JC (1999) Temperature dependence of inorganic nitrogen uptake: reduced affinity for nitrate at suboptimal temperatures in both algae and bacteria. Appl Environ Microbiol 65: $2577-2584$

Reinthaler T, Herndl GJ (2005) Seasonal dynamics of bacterial growth efficiencies in relation to phytoplankton in the southern North Sea. Aquat Microb Ecol 39:7-16

Revilla M, Iriarta A, Madariaga I, Orive E (2000) Bacterial and phytoplankton dynamics along a trophic gradient in a shallow temperate estuary. Estuar Coast Shelf Sci 50: $297-313$

Rivkin RB, Legendre L (2001) Biogenic carbon cycling in the upper ocean: effects of microbial respiration. Science 291: 2398-2400

Roland F, Cole JJ (1999) Regulation of bacterial growth efficiency in a large turbid estuary. Aquat Microb Ecol 20:31-38

Rose AH (1967) Thermobiology. Academic Press, London

Sampou P, Kemp WM (1994) Factors regulating plankton community respiration in Chesapeake Bay. Mar Ecol Prog Ser 110:249-258

Sherr BF, Sherr EB (1996) Temporal offset in oceanic production and respiration processes implied by seasonal changes in atmospheric oxygen: the role of heterotrophic microbes. Aquat Microb Ecol 11:91-100

Shiah FK, Ducklow HW (1994a) Temperature and substrate regulation of bacterial abundance, production and specific growth rate in Chesapeake Bay, USA. Mar Ecol Prog Ser 103:297-308

Shiah FK, Ducklow HW (1994b) Temperature regulation of heterotrophic bacterioplankton abundance, production, and specific growth rate in Chesapeake Bay. Limnol Oceanogr 39:1243-1258

Smith DC, Azam F (1992) A simple, economical method for measuring bacterial protein synthesis rates in seawater using super(3)H-leucine. Mar Microb Food Webs 6:107-114

Smith EM (2000) Factors regulating respiration and its coupling to primary production in a coastal planktonic community. PhD dissertation, University of Maryland, Cambridge, MD

Tibbles BJ (1996) Effects of temperature on the incorporation of leucine and thymidine by bacterioplankton and bacterial isolates. Aquat Microb Ecol 11:239-250

Tison DL, Pope DH (1980) Effect of temperature on mineralization by heterotrophic bacteria. Appl Environ Microbiol 39:584-587

Toolan T (2001) Coulometric carbon-based respiration rates and estimates of bacterioplankton growth efficiencies in Massachusetts Bay. Limnol Oceanogr 46:1298-1308

Vincent WF, Dodson JJ, Bertrand N, Frenette J (1996) Photosynthetic and bacterial production gradients in a larval fish nursery: the St. Lawrence River transition zone. Mar Ecol Prog Ser 139:227-238

Zar JH (1984) Biostatistical analysis. Prentice-Hall, Englewood Cliffs, NJ

Zumdahl SS (1989) Chemistry. D. C. Heath \& Company, Lexington, MA

Submitted: December 12, 2005; Accepted: March 31, 2006

Proofs received from author(s): June 26, 2006 